\title{
A Critical Study of Blasphemy Laws of Pakistan and their Impact on the Minorities of the Country
}

\begin{tabular}{|l|}
\hline Published: \\
28-12-2020 \\
Accepted: \\
26-11-2020 \\
Received: \\
25-10-2020 \\
\hline
\end{tabular}

\author{
Dr.Abdul Muhaiman \\ Assistant Professor, Department of Islamic \& Religious \\ Studies, University of Haripur, KPK \\ Email: muhaimin74@gmail.com \\ Muhammad Hayat Khan \\ Ph.D Scholar, Department of Islamic and Religious Studies, \\ University of Haripur, KP. \\ Email:hayat.khan715@gmail.com
}

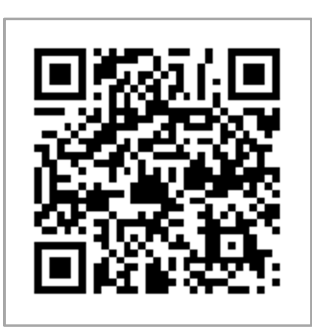

\begin{abstract}
$\underline{\text { Abstract }}$
The blasphemy laws are the parts of Pakistan Penal Code which were set up by the British regime in 1860. These laws were aimed to safeguard the religious feelings of the followers of various beliefs. The laws encompassed all the religions who lived in the subcontinent. It is also said that the sections 295-B and 295-C which were introduced in 1980s are meant to shield only one religion and that is Islam. This research has critically examined the blasphemy laws of Pakistan and their impacts on the status of non-Muslims living in the country. The study has highlighted views of the adherents and the opponents of these laws. It gives a fact sheet of what has happened so far in the country in terms of the outcomes of these laws. The research includes a recent survey on issue related to blasphemy and it ends up with few recommendations.
\end{abstract}

Keywords: Blasphemy, Hanafischool of thought, Qur'än, Hadith, Shari'at, Four rightly guided Caliphs, Umayyad, Abbasids.

\section{Blasphemy:}

Blasphemy means to make a mention of the sanctities of any religion in a way that offends followers of that religion. Various definitions of blasphemy can be found in legal dictionaries. For instance irreverent or profane speech or writing about religion or sacred things. ${ }^{1}$ And blasphemy is the offense of speaking matter relating to God, Jesus Christ, the Bible or the Book of Common Prayer, intended to wound the feelings of mankind or to excite contempt and hatred against the church by law established, or to promote immorality. ${ }^{2}$ In Muslim societies blasphemy encompasses the sacredness the Prophet (PBUH) and the Holy Qur'ān.

\section{The Law itself:}

Pakistan Penal Codes has 2 sections and 3 sub sections of blasphemy laws and the details of these laws are; 295. Injuring or defiling place of worship, with intent to insult the religion of any class: Whoever destroys, damages or defiles any place of worship, or any object held sacred by any

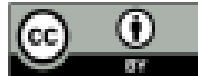


class of persons with the intention of thereby insulting the religion of any class of persons or with the knowledge that any class of persons is likely to consider such destruction damage or defilement as an insult to their religion, shall be punished with imprisonment of either description for a term which may extend to two years, or with fine, or with both.

295-A. Deliberate and malicious acts intended to outrage religious feelings of any class by insulting its religion or religious beliefs: Whoever, with deliberate and malicious intention of outraging the religious feelings of any class of citizens of Pakistan, by words, either spoken or written, or by visible representations insults the religion or the religious beliefs of that class shall be punished with imprisonment of either description for a term which may extend to ten years, or with fine, or with both.

295-B. Defiling of Holy Qur'ān: Whoever willfully defiles, damages or desecrates a copy of Holy Qur'annor of an extract therefrom or uses it in any derogatory or for any unlawful purpose shall be punishable with imprisonment for life.

295-C. Use of derogatory remarks, etc., in respect of the Holy Prophet: Whoever by words, either spoken or written, or by visible representation or by any imputation, innuendo, or insinuation, directly or indirectly, defiles the sacred name of the Holy Prophet Muhammad (PBUH) shall be punished with death, or imprisonment for life, and shall also be liable to fine. ${ }^{3}$

\section{Adherents of the Laws:}

There has been long debate on the legitimacy of blasphemy law of Pakistan. The adherents and opponents have come up with their arguments. A summary of the perspective of the advocators of the law is briefly presented here.

The blasphemy law is in fact aimed to protect the dignity of the source of the guidance for all the human beings and on which the legal, constitutional, social and cultural structure of Islam stands. To challenge the sacredness of this divine guidance means to challenge this complete system of guidance. And that is why in Muslim societies anything related to Prophet (PBUH) becomes very sensitive. The blasphemy law in Pakistan is not based on any religious prejudice or extremism; rather it is purely in line with Islamic traditions. ${ }^{4}$ The advocators of this law are of the opinion that the following verses of the Holy Qur'anstrongly support the death sentence for blasphemy offence;

But if they violate their oaths after their covenant, and attack your religion with disapproval and criticism then fight (you) the leaders of disbelief for surely their oaths are nothing to them - so that they may stop (evil actions). ${ }^{5}$

Verily, those who annoy Allah and His Messenger (PBUH), Allah has cursed them in this world, and in the Hereafter, and has prepared for them a humiliating torment. ${ }^{6}$ 
Verily, those who oppose Allah and his Messenger (PBUH) will be disgraced, as those before them (among the past nation), were disgraced. And we have sent down clear versesand for the disbelievers is a disgracing torment. $^{7}$

According to the supporters of this law there are many more verses in the Holy Qur'anin support of their argument. And a Muslim scholar has mentioned twenty two verses of the Holy Qur'anand forty traditions of the Prophet (PBUH) in favor of blasphemy law. ${ }^{8}$ According to IbnTymiyah ${ }^{1}$ the accused of blasphemy offense must be killed according to the consensus of the companions of the Prophet (PBUH) and there are many incidents which support this consensus. Not a single companion of the Prophet (PBUH) has gone against this agreement. ${ }^{9}$ The adherents of blasphemy law have focused on Muslim history and have tried to prove that this law unanimously existed throughout Muslim history with full agreement of all schools of thought.

All the companions of the Prophet (PBUH) are agreed on the point that the accused of the blasphemy law must be killed and there is no disagreement between ancient and modern scholars in this issue. ${ }^{10}$ The reign of the four rightly guided Caliphs was also a replica of the time of the Prophet and they also announced the death penalties for the accused of blasphemy. And same was the case in the time of Umayyad and Abbasids. ${ }^{11}$ All four Muslim schools of thought are agreed on the killing of those who insult the Prophet. Only Hanafischool of thought adds the condition that the accused must go on with the offense. ${ }^{12}$ One of the leading Hanafischolars say that there is no disagreement among the Muslims that whoever abuses the Prophet is not a Muslim and he deserves to be killed. ${ }^{13}$

The adherents of blasphemy law are of the opinion that Pakistan is not a secular state and it was separated from British India on religious grounds and its constitution was designed accordingly.

The constitution of Pakistan guarantees the rights to its all nonMuslims citizens but there are certain obligations as well. And these obligations must be perceived in connection with the feelings of the people and accordingly interpreted. Few people show dissatisfaction on the blasphemy laws of Pakistan because they think that these laws are not in line with the charter of human rights provided in the constitution of the country. They must understand that the Muslims of Pakistan do not accept the right of anyone, Muslims or non-Muslims, to abuse the religion of prophet of any other religion. Others think that blasphemy laws of Pakistan are not parallel with modern secular ideologies. They must remember that Pakistan is not a secular state and it was not built on secular grounds. Rather it was established on pure religious foundations and that is why the people of Pakistan cannot act like the people of any secular country. ${ }^{14}$

\footnotetext{
${ }^{1}$ IbnTymīyah(1263-1328AD) was a great Muslim Sunni scholar.
} 


\section{Adversaries of the Laws:}

Those scholars who do not support the blasphemy law of the country have got a different point of view. They also mention the verses from the Holy Qur'anand interpret them differently. According to them there are no foundations for this law in the Qur'än. For instance they quote and explainthe following verse;

The Recompense of those who wage war against Allah and his Messenger and do mischief in the land is only that they shall be killed or crucified or their hands and their feet be cut off on the opposite sides, or be exiled from the land. That is their disgrace in this world, and a great torment is theirs in the hereafter. Except for those who (having fled away and then) came back (as Muslims) with repentance before they fall into your power; In that case, know that Allah is OftForgiving, Most Merciful. ${ }^{15}$

It is obvious from the style of these verses that the meaning implied by waging war against Allah and his Prophet (PBUH) and spreading anarchy in the land is that an individual or a group of individual rebels against the Islamic law of the Almighty and attacks the life, wealth, honor and freedom of expression of people. ${ }^{16}$

The law for punishing blasphemy against the Prophet (PBUH) that is invoked in Pakistan has no foundation in the Qur'an or Hadith. Therefore a pertinent question is: What exactly is the justification for this law. Some scholars have proffered the above mentioned verse of the Qur'anas a possible basis. In their opinion, Allah is these verses have prescribed the punishment of rebellion and disorder, and they believe that blasphemy against the Prophet (PBUH) is also a form of this offense. ${ }^{17}$

As other viewpoints on foundations for blasphemy laws, this opinion too needs to be reviewed for the following reasons: firstly, the word used in this verse means they fight/rebel against. This word entails that the sentence of punishment in this verse be given only if the offender persists in blasphemy defiantly, resorts to disruption or disorder, refuses to desist even after repeated exhortation and admonition and, in contrast to an attitude of consequent submission, and actually takes a stance of retaliation. On the other hand, if the accused pleads that he is not guilty or gives an excuse to explain his attitude and shows no violation for persistence, he cannot, in any sense of the word, be indicated for fight or rebellion. ${ }^{18}$ Secondly, the Qur'ansays that the sentence will not be applicable to those offenders who, despite their prior proclamation and persistence, submit and repent before the law apprehends them. Therefore the directive is that those who have repented shall not be given these sentences. This aspect also entails that, before any action is taken against such offenders, they be called to repent and reform and be repeatedly warned that, if they are believers, they should not destroy their own future in the hereafter by their wrong attitude or notions, and if they do not believe in Allah and the Prophet (PBUH), they should show regard for the feelings and sentiments of Muslims and abstain from this grave violation any further. 
Thirdly, the verse does not make capital punishment obligatory. It gives the court room for a lenient sentence in consideration of the nature of offense and the state of the offender. The recommendation of banishment in the verse is for such offenders as deserve leniency. ${ }^{19}$

In the present law, none of the aspects mentioned above has been considered. For sentencing, this law depends solely on testimony. There is no consideration whatsoever for confession or denial, which consideration the verse entails; there is no room for clemency on the repentance and reform shown in response to exhortation and admonition; and as such, there is no other option except capital punishment. It would indeed be commendable even if the scholars were to accept the above mentioned verse as the foundation for blasphemy punishment and,consequently, show willingness to have amendments made to the existing law. Even that would end all criticism on the present law. It is obvious from the Qur'anthat capital punishment can only be given in two cases; first if a person murders another and, second, if he disrupts law and order in the country and, as such, becomes a threat to the life, property and honor of people. If the law is amended in accordance with the requirements of the verse, the requirement of confining capital punishment to these two cases will be fulfilled. ${ }^{20}$

\section{The Prophet's Practice:}

In between the arguments of the adherents and the opponents of the law, the most important factor is the dealing of the Prophet (PBUH) with the accused of blasphemy. And there are two different aspects of this dealing of the Prophet $(\mathrm{PBUH})$. There were many times when the Prophet (PBUH) advocated the punishment for the accused of blasphemy and at times it was death sentence as well. This is very important to take into the consideration that the Prophet (PBUH) himself was there and he had the divine authority to execute such punishments. Secondly, there are many incidents quoted from the Prophet (PBUH) when he forgave the accused of blasphemy. All those scenarios of blasphemy which had far reaching impacts on Muslim societies were dealt strictly. And all those incidents of blasphemy which were related to his own self, he forgave the accused. The following Hadithof the Prophet (PBUH) sums up the whole argument. 'Ayishahreports that the Prophet $(\mathrm{PBUH})$ did not take revenge for himself unless the limits of Allah were violated. Then he took revenge for it for Allah. ${ }^{21} \mathrm{~A}$ few incidents from the life of the Prophet in which he supported the death sentence for the accused of blasphemy are;

Reports Ibn 'Abbāsthat a woman despite many warningsused to blaspheme the Prophet (PBUH) and she was killed and the Prophet (PBUH) after knowing about the incident said that no retaliation is payable for her blood. $^{22}$

In another incident sister of 'Umyr Bin Umayyahused to taunt 'Umyrby using foul language about the Prophet (PBUH). 'Umyrkilled his sister and 
reported the incident to the Prophet, who after investigating the matter announced that there is no retaliation payable for the blood. ${ }^{23}$ And at the time of the conquest of Mecca, the Prophet (PBUH) decreed death sentence for two slave girls who used to sing abusive poems about the Prophet (PBUH). ${ }^{24}$

Few other incidents from the life of the Prophet where he did not punish those who blaspheme him are;

Narrated 'Aishahthat a group of Jews entered upon the Prophet (PBUH) and said death be upon you. I ('Aishah) understood it and said that death and the curse of Allah be upon you. The Prophet (PBUH) said, "Be calm $\mathrm{O}$ 'AishahAllah loves kindness in all matters. ${ }^{25}$

In another incident a Jewess from Khybarpoisoned a roasted sheep and presented it to the Prophet (PBUH) who ate from it. The woman confessed that she poisoned the food to kill the Prophet.The companionsof the Prophet wanted to kill the women but he did not allow them and forgave her. ${ }^{26}$

A man from pagans came while the Prophet's (PBUH) sword was hanging on the tree. He took it out of its sheath secretly and said to the Prophet (PBUH), 'are you afraid of me?' The Prophet (PBUH) said, 'No' He said, 'who can save you from me?' The Prophet (PBUH) said, 'Allah'. He put the sword in the sheath and the Prophet (PBUH) did not punish him. ${ }^{27}$

The above mentioned incidents from the life of the Prophet (PBUH) reveal two different and very significant aspects of his life. Firstly, in his personal capacity he was a very humble and meek man who never took revenge for his own self. On the other hand in his capacity as the messenger of Allah, he was bound to establish the sovereignty of his Lord on the land. And for this he took even cohesive measures and punish those who tried to hinder this divine decree and this is where the following verse was applied;The Recompense of those who wage war against Allah and his Messenger and do mischief in the land is only that they shall be killed or crucified or their hands and their feet be cut off on the opposite sides, or be exiled from the land. ${ }^{28}$

\section{Fact Sheet of Pakistani Society regarding Blasphemy:}

Regardless of the debate of the legitimacy of the blasphemy law of Pakistan, it is of great concern to look at what has so far happened in the country in connection with blasphemy law. This gives a very clear picture of Pakistani society and the status of non-Muslims living therein.

Between 1927 (year in which British colonial rulers introduced section 295-A) and 1986 there had been less than ten reported cases of blasphemy. However, 1986 onwards as many as 4,000 cases have been reported. Between 1988 and 2005, Pakistani authorities charged 647 people with offences under the Blasphemy Laws. Fifty percent of the people charged were non-Muslims. More than 20 people have been murdered for alleged blasphemy. Two third of all the cases are in the Punjab Province of Pakistan. The province of the Punjab is home to 81 percent of Pakistnan's Christians. The seven districts that have contributed most to the blasphemy cases are Lahore, Faisalabad, Sialkot, 
Kasür, Sheikhupüra, Gujranwala and TübaTek Singh. The total population of these districts is 25 million, of which five percent are Christian; 50 percent of total Christian population of Pakistan of 2.0 million lives in these seven districts; majority of Christians in the Punjab live in rural areas.According to 1998 Census, the population of religious minorities, in Pakistan, is around six million or 3.7 percent of the total population. The Hindus and Christians constitute 83 percent of the religious minorities in Pakistan, with Hindus outnumbering Christians by a small margin and 93 percent of Hindus live in Sindh.An analysis of 361 cases of blasphemy offences registered by the police between 1986 and 2007 shows that as many as 49 percent cases were registered against non-Muslims. The cases against non-Muslims should be contrasted with the population of religious minorities which is not more than four percent of Pakistan's population. Moreover, 26 percent cases against Ahmadis and 21 percent cases against Christians are not in line with their ratio in total population, which is 0.22 and 1.58 percent of the total population respectively. The number of persons nominated in 361 cases was 761. Out of 361 total cases, more than two-thirds cases were found to be from the Punjab, 15 percent from Sindh and 5 percent from the KhybarPakhtunkha ${ }^{2}$.

Out of 35 districts in the Punjab, police in seven districts - all in central Punjab - had registered 10 or more cases during 1986 and 2007.Forty one percent of all cases in terms of religion were registered. Nearly 65 percent of cases registered were against Christians, and Muslims were nominated in 43 percent cases.A total of 104 cases reached the higher courts between 1960 and 2007, out of which 91 cases were heard by the High Courts in Pakistan and the $\mathrm{AJK}$ and the rest by the apex courts (Supreme Court and Shari' at Court). In as many as 41 cases, section 295-C was invoked.

A study of data and cases study, suggest that there are three types of blasphemy cases:

i) cases which are mere accusations and are lodged to settle scores; ii) cases which are based on expressing one's faith, and iii) cases in which the accused are known to be suffering from some kind of mental illness. ${ }^{29}$

\section{Few Incidents Relating to Blasphemy in Pakistan:}

It is also worth mentioning a few incidents recently happened in Pakistani society which will help in a better understanding of on ground realities.

\section{AāsīyahNorīn:}

In November 2010, AāsìyahNorin was sentenced to death, accused of insulting Prophet Muhammad (PBUH). ShahbazBhatti, a Christian minister of minorities and Salam Tasir, ${ }^{3}$ governor of Punjab ${ }^{4}$, were both killed for

\footnotetext{
${ }^{2}$ Sindh and KhybarPakhtunkha are two of five provinces of Pakistan.

${ }^{3}$ A Pakistani businessman and politician, who was the governor of Punjab from 2008
} 
advocating on her behalf and for criticizing the blasphemy laws of the country. AāshiqMasih the husband of Aāsiyahwrote a letter to the president of Pakistan to grant her official pardon and to allow her to move to Paris which is offering to welcome their family. Aāshiq added that she is being kept in dreadful conditions and the whole family is living in terror. The lawyer of Aāsìyahis also living a terrified life.

\section{MuhammadAsghar}

Muhammad Asghara British with Pakistani origin is an old man with mental illness was sentenced to death for claiming to be prophet in September 2010. Asgharwas shot inside the prison in the city of Rawalpindi.

\section{Joseph Colony Incident:}

A Christian man SäwanMasìh was convicted of insulting Prophet Muhammad (PBUH) while he was talking to his friend in Lahore in March 2013. Säwan was of the opinion that the real reason for blasphemy allegation was his property dispute with his friend. Whatever was the case, the attack of more than three thousand men on Christian homes and burning more than hundred houses cannot be justified by any means.

\section{KūtRāhdāKishan:}

In November 2014, a Christian couple named Sham'a andShehzād were beaten to death and were burnt in a brick kiln after they were accused of desecrating a copy of the Holy Qur'ān.

\section{Yūhanabād:}

In March 2015, there were bomb blasts in two churches in Lahore in which 17 people were killed. In reaction, there were violent demonstrations and two Muslims named $N a^{\prime} i m$ and Babar $A^{\prime}$ wàn were burnt alive to death by Christian mob.

\section{RimshaMasih}

An 11 year Christian girl was accused of burning the Holy Qur'ān by a Muslim cleric. It was later on found that the cleric fabricated facts and the case against Rimsha was dropped. But she, with her family spent several months in hiding before she fled to Canada. The lawyer of Rimshasaid that if she is not convicted, Muslims could take the law into their own hands.

The incidents regarding blasphemy have created a constant fear in the minorities and they live under a threat of attack by the mob at any moment. One person may be found guilty of blasphemy but the whole community is put into hazard. The minorities are of the opinion that if a Muslim is found guilty, the whole Muslim community is not threatened. According to them the minorities of the country are living in the sense of exclusion and deprival. Last

to 2011. He was assassinated by his own bodyguard, MumtāzQādrī. A mosque has been named in the honor of Qädrinear Islamabad.

${ }^{4}$ Punjab is the most populous province of Pakistan. 
year, there were more than 100 blasphemy cases registered. Since 1991, 62 people accused of blasphemy have been murdered by vigilantes, more than half of those in the last five years.

\section{Survey:}

A survey was conducted specifically for this research in the University of Haripur and its surroundings in KhyberPakhtunkha province of Pakistan. The participants of this survey were asked a few questions related to the blasphemy law of the country. About 384 people were questioned in regard with the issue which included 24 people having doctorate, 41 were M.Phil, 63 had master's degree, 91 had bachelor's degree, 80 were intermediate while 38 people were under matriculation and the rest were illiterates. 233 of these were male and 151 were female. The questions asked were;

1. Have you ever studied the blasphemy law of your country?

$95 \%$ people answered that they did not study it.

2. What in your thought should be the punishment of blasphemy?

$78 \%$ said death penalty, $9 \%$ said imprisonment for life and $13 \%$ did not answer this question.

3. Should Samlan Tasir and Shahbaz Bhatti be killed?

$42 \%$ said Yes, $18 \%$ said No and $40 \%$ could not answer this question.

4. Are the minorities protected and living in peace in Pakistan?

$24 \%$ said Yes, while $58 \%$ said No and $18 \%$ said that they did not know.

5. Is the assassinator of Salman Tasira national hero?

$57 \%$ said Yes, $18 \%$ No and $25 \%$ could not answer.

An analysis of the data collected through the survey gives a very good reflection of the awareness prevails in Pakistani society in regard with blasphemy laws. The collected data replicates that the statements given by the participants of this survey are very contradictory. For instance $95 \%$ of the participants did not study the law itself but the majority wants death sentences for the accused of the law. When it comes to the killing of those who showed sympathy to the accused, majority said that they must be killed and the killer is considered a national hero by most of the participants. Interestingly, majority of the participants said that it is hard for non-Muslims to live in peace in Pakistan.

\section{Conclusion:}

It can be concluded from all the arguments and facts mentioned about blasphemy law of Pakistan that the issue is very significant and sensitive. The emotions of the people are attached to this is issue and the debate of bringing 
any changes in the law will further instigate the emotions of the people which could ultimately lead to violence and anarchy and this has happened so many times in recent past. As a matter of fact the minorities of the country have to suffer the most as a result of such violence. It is obvious that a common man is neither aware of the law itself nor about the life and the practice of the Prophet regarding blasphemy. And this unawareness and ignorance makes them take the law into their own hands. Having all this in mind a few recommendations are made here;

\section{Recommendations:}

- Anyone accused of blasphemy may be asked to reconsider what he said and to repent. He may be advised not to do this, if he believes in Allah and his Messenger Muhammad (PBUH). In case he is not a Muslim he should respect the feelings of Muslims.

- In case he refuses to do repent and insists on what he has said, he may be reported to law enforcing agencies.

- The offense may closely be examined and death sentence may not be applied in each and every case.

- There must be a difference in an effort to insult Islam or its Prophet and criticism made on the teachings of Islam.

- Before expecting respect for Islam from the followers of other religions, we will have to show respect and dignity to other religions and to their believers.

- There is a dire need to create awareness in connection with blasphemy laws of the country and religious scholars have to play a vital role in this regard.

- One must make sure that it is an offence and then inform police as individuals have no right to take laws into their hands.

- Showing insult and rudeness to anyone is a condemnable act and every society reserves the rights to form such rules and regulations which may stop such denouncing acts. But this is even more important to critically examine the outcomes and impacts of such laws. It is not the laws which are the real focus but it is the result of these laws. If the laws are not bringing up the expected results, two things can be done, one is to change the law. In case it is not possible to change the law, the other option is to adopt any other means such as counseling and preaching which may bring up the desired results. 
This work is licensed under a Creative Commons Attribution 4.0 International License.

\section{References}

1 Blackwell, Amy Hackney, The Essential Law Dictionary, (Illinois: Sphinx Publishing, 2008), 56.

2 Black, Henry Campbell, Black's Law Dictionary, (Saint Paul Minn, West Publishing Co, 1968), 216.

${ }^{3}$ Pakistan Penal Code (XVL of 1980), Chapter XV, 108.

${ }^{4}$ Ghāzì, MaḥmūdAḥmad,QānūnTūhìn-e-Risālat, (Islamabad: Sharī‘ahAcademy, 2014), 13.

${ }^{5} \mathrm{Al}$ Qur'ān (9:12)

${ }^{6}$ Al Qur'ān (33:57)

${ }^{7}$ Al Qur'ān (58:5)

${ }^{8}$ Thānvī, JamīlAḥmad, Blasphemy and its Punishment, (Lahore: IdārahIslāmìyāt, 1994), 14-25.

${ }^{9}$ IbnTymīyah, Taqī Al Dīn, Al Șārim Al Maslūl, (Mecca: Dār Al 'Alam, 2001),78.

${ }^{10}$ AbūFazal, Qāọī 'Ayāẹ, Al Shifā, (Beirut: Dār Al Kitāb, 1984), 932.

${ }^{11}$ Qureshī, Muhammad Ismā'îl, NamūseRisālat, (Lahore: Al FyṣalBook Dealers, 1994), 112-116

${ }^{12}$ Qamar, Muhammad Munīr, HuqūqeMușțafā, (Gujranwala: Um Al QurāPublications, 2011), 342.

${ }^{13}$ Al Jaṣāṣ, AbūBakrAḥmad, Al Aḥkām Al Qur'ān, (Beirut: Dār Al Ahyāan, 1992), Sec. 3, 86.

${ }^{14}$ Ghāzī, MaḥmūdAḥmad, op.cit.,41.

${ }^{15} \mathrm{Al}$ Qur'ān $(5: 33,34)$

${ }^{16}$ Ghāmdī, JāvedAḥmad, The Penal Sharī'ahof Islam, (Lahore: Al Mūrid, 2004), 8.

${ }^{17}$ Ghāmdì, JāvedAḥmad, Maqāmāt, (Lahore: Al Mūrid, 2014), 270.

${ }^{18}$ Ibid., p. 271.

${ }^{19}$ Ibid.,p. 272.

${ }^{20}$ Ibid.,p. 273.

${ }^{21}$ SahịhBukhārì, Section 9, p. 88.

${ }^{22}$ SunanAbīDāwūd, Section 11, p. 437.

${ }^{23}$ Majma' AlZawā'id, Section 6, p. 260.

${ }^{24}$ SìrahIbnHishām, Section 5, p. 70.

${ }^{25}$ SaḥịhBukhārī, Section 15, p. 215. 
${ }^{26}$ SunanAbīDāwoùd, Section 12, p. 98.

${ }^{27}$ SahịhBukhārī, Section 13, p. 37.

${ }^{28}$ Al Qur'ān (5:33)

29 "Pakistan Blasphemy Laws: A Fact Sheet," Citizens for Democracy, accessed June 10, 2015, https://citizensfordemocracy.wordpress.com/2011/50/05/pakistan-blasphemylaws-a-fact-sheet/ 